\title{
Racial Inequality in Brazil from Independence to the Present
}

\author{
Justin R. Bucciferro
}

\section{Introduction}

There is a broad effort to reduce racial inequality in Brazil and, over the past decade or two, it appears to have been successful. Affirmative action was introduced under the Secretary of State for Human Rights in 2002, for example, and a new Secretary of Policy for the Promotion of Racial Equality was established in 2003. Disparities between races - formally defined as black (preto), white (branco), mixed-race (pardo), Asian (amarelo), and indigenous (indígena)- have declined in terms of literacy (Rossetto and Paixão 2010), level of schooling (Marteleto 2012), and employment and earnings (International Labor Organization 2007), although not university enrollment (IBGE 2008). Is this recent experience attributable to policy or part of a much longer trend?

This chapter considers racial inequality in Brazil back to the colonial era (pre1822), addressing the social construction and historiography of race, and illustrating the comparative size of racial groups over time. The relative well-being of Afro-Brazilians (pardos or pretos) and whites (brancos) is described across major historical periods - the Imperial Era (1822-1889), First Republic (1889-1930), Vargas Era (1930-1945), Second Republic (1946-1964), Military Rule (1964-1985), and Return to Democracy (1985 to present) - in terms of life expectancy, literacy, primary school completion, years of schooling, occupation, and income.

Race is somewhat arbitrary, but nonetheless meaningful given the drastic differences across groups and their reproduction over time. During the late eighteenth and nineteenth century, Brazil was predominantly black or mixed race; over the twentieth century, white; and in the twenty-first century, again Afro-Brazilian. In the Imperial Era, slaves were employed throughout the economy, but they comprised a

\footnotetext{
J.R. Bucciferro $(\bowtie)$

Department of Economics, Eastern Washington University,

311 Patterson Hall, Cheney, WA, 99004, USA 
declining share of the population: $5 \%$ of Brazilians and fewer than $10 \%$ of blacks and mulattos upon abolition. Net hire rates for slaves between 1870 and 1887 from Mello (1977) and wage rates for day laborers from Dean (1976) suggest that a slave received in kind just $35 \%$ of what a free laborer could earn.

In the southeast after abolition, favored colono or settler contracts were given to European immigrants, whereas blacks left the plantation or found unstable employment as camaradas or day laborers. Elsewhere in Brazil, former slaves were integrated back into the plantation economy as wage laborers. In urban São Paulo, the race and occupation of individuals from Incident Reports spanning 1912-1920 (from Jacino 2012) combined with average salaries from the 1920 census reveal that blacks were overrepresented in the lowest paying jobs; further wage discrimination suggests that blacks earned as little as $40 \%$ of whites.

The situation of Afro-Brazilians improved after Vargas took power in 1930, and through the economic boom of the 1950s, as blacks became politically organized and made relative gains in terms of both industrial employment and literacy. During the military dictatorship, however, black activism was curtailed and occupational or wage discrimination appears to have increased. In contrast, recent decades have witnessed the public recognition of Afro-Brazilian disadvantage and the introduction of targeted policies to ameliorate racial inequality.

Overall, racial groups became more equal during the twentieth century. There was a rise in literacy, education, and income for all groups, and a decline in occupational segregation; the relative status of nonwhites was variable, however, and only began to noticeably improve around 1980. Black-and-white income during the 1980s and 2000s converged moderately, in contrast to the divergence of Asian and indigenous income during the former period and real declines for both groups in the latter. Only in the past 10 years has the black-white income gap narrowed beyond its 1960 level, although it is now probably at its lowest point ever.

This investigation expands upon the analyses of Hasenbalg (1978), Silva (1985), and Lovell (1999) which parts from the 1960 decennial census, and integrates additional census and annual survey data after 1980 as employed by Arcand and D'Hombres (2004), Arias et al. (2004), and Campante et al. (2004). Race is an important aspect of inequality and this analysis is unique in providing a narrative of national trends in relative well-being which spans the breadth of Brazil's postcolonial history.

\section{Conceptualizations of Race in Brazil}

A "race" is defined as a group of people with a common ancestry, or sharing certain physical markers such as skin tone, hair texture, and facial features. Such traits may not necessarily be indicative of one's genetic origins, though, particularly within the demographic milieu that is the New World. Regardless, there is no biological basis for classifying humans into racial groups, and the (untestable) postulate must therefore be accepted that no so-called race is inherently inferior to another. 
If race is an arbitrary concept, why is it so powerful in explaining relative outcomes? Race - "a socially constructed mode of human categorization," (Loury 2002; p. 5) - is imbued with meaning upon which individuals act, for which it retains its currency. If a group is stereotyped as being inexperienced, for instance, people within this group may receive fewer job offers and, indeed, come to have less experience. In this section, the origins of "race," the changing social meanings which have been attributed to groups in Brazil, and the historiography of race in Brazil are described from the early twentieth century to present.

Prior to the fifteenth century, when slave production was introduced on the Atlantic islands and the "New World" was revealed to Europeans, the nature of slavery was quite different: one's status as a slave was less directly related to his or her race or ethnicity, and slaves had a greater possibility of someday integrating into society as freemen (Klein 2010). In the colonies of the Americas, the scale and harshness of slavery were unprecedented: over ten million African slaves survived the middle passage over the course of the traffic (Trans-Atlantic Slave Trade Database), many of whom spent the remainder of their lives producing sugar, coffee, cotton, and other commodities. The system required justification, an underlying ideology which could ensure its continuation amidst acute inequality, hence the invention of race.

The differential status of Europeans, Natives or "Indians," and Africans in the New World was institutionalized by both church and state. The legacy of fifteenthcentury inquisition thinking was that Indians possessed a soul whereas Africans did not; in response to the rapid decline of native populations during colonization, the Spanish and Portuguese crowns prohibited their (unjust) enslavement in the 1540s. The result was an increasing reliance on African slaves: in Brazil, the workforce on coastal plantations came to be predominantly African by the beginning of the following century (Klein and Luna 2010).

The relative size of Afro-Brazilian and white populations over time is a rough indicator of inequality because similar numbers of African slaves and European immigrants ultimately arrived in Brazil - what better measure of long-run adaptive success is there than a group's ability to survive? Consider the cumulative number of slaves imported up until each period and, separately, the cumulative number of immigrant arrivals: the size of the "flow" versus the "stock" gives a crude sense of the fate of each group.

An estimated 5.5 million African slaves were shipped to Brazil (4.9 million disembarked) over three centuries of the Atlantic slave trade, relatively close to the population of 5.8 million "blacks" in $1872 .{ }^{1}$ While this implies a zero natural increase, there is ample evidence of positive growth of the free black population during the eighteenth century, suggesting an offsetting negative change among slaves. Negative growth of the slave population implies, in turn, high mortality rates and low living standards. In contrast, the white population increased sixfold between 1820 and 1890, to six million; yet fewer than two million immigrants had arrived

\footnotetext{
${ }^{1}$ Estimated number of slaves who embarked for Brazil, according to the Trans-Atlantic Slave Trade Database (http://slavevoyages.org), accessed 11/2014.
} 
until that time. ${ }^{2}$ In short, the demographics imply a very big gap in the black-white mortality rates and in living standards in the nineteenth century. The flow of immigrants only reached the volume of the slave trade in 1950, at which point the white population numbered over 32 million.

The Portuguese who settled colonial Brazil were predominantly men (as were two-thirds of African slaves), and had children of mixed indigenous, African, and European ancestry. According to Ribeiro (1995), the children of Europeans and Indians (mamelucos or mestiços) and Africans (mulattos) were prototypical of a new unified people: Brazilians. The importance of racial markers, however, indicates a lesser degree of assimilation than Ribeiro implies; nonetheless, race is a qualitatively different concept in Brazil than in other countries.

The current classifications of race can be traced to at least the eighteenth century: In 1776, Portugal issued a circular which ordered a census to include counts by age and sex; although not required, some governors decided to collect racial information as well (Alden 1963). The population was classified into three or four racial groups: brancos (whites), pardos (literally "browns"; mulattos), pretos ("blacks"; Negroes), and indios (Christian Indians). In subsequent regional censuses, alternative terms like caboclo (Indian or mestiço) have been used, always omitting un-contacted aboriginals.

Beginning with the first national census of 1872 and continuing through the most recent decennial censuses, the same general racial categories have been employedbranco, pardo, preto, and índigena-as well as amarelo (literally "yellow" or Asian); however, race was not included in the 1920 or 1970 censuses, and "Indian" was not a category in the 1940 census. The racial makeup of Brazil, according to national censuses from 1872 to 2010 and earlier figures as compiled by Bucciferro (2013), is shown in Fig. 1.

The population of the colonies, excluding un-contacted aboriginals, was primarily indigenous until 1725; around 1750, people of African descent became the predominant racial group and remained so until the mass immigration of whites between 1890 and 1940. During the twentieth century the majority were white, but in the most recent census it was again Afro-Brazilian. Two key questions emerge: Is such a broad color-based classification meaningful? Does it correspond to the social construction of race as formalized by individuals?

One issue is that mestiço, of mixed Indian and European descent, is not included as a category in the census; therefore such individuals may classify as either pardo or branco. Furthermore, individuals of mixed African and European descent may also be classified as pardo or branco, hence such outmoded terms as branco da terra (light-skinned mestiço) and branco da bahia (light-skinned mulatto). Individuals within each group are invariably of mixed descent, which belies the biological determinism associated with race.

Scholars have generally considered racial disparities in terms of a white/ nonwhite or white/brown/black categorization, but its validity has been questioned

\footnotetext{
${ }^{2}$ Number of immigrants who arrived in Brazil, according to IBGE, 500 anos de povoamento, Rio de Janeiro: IBGE, 2000; for figures prior to 1820 and after 1975, only Portuguese immigrants are included.
} 


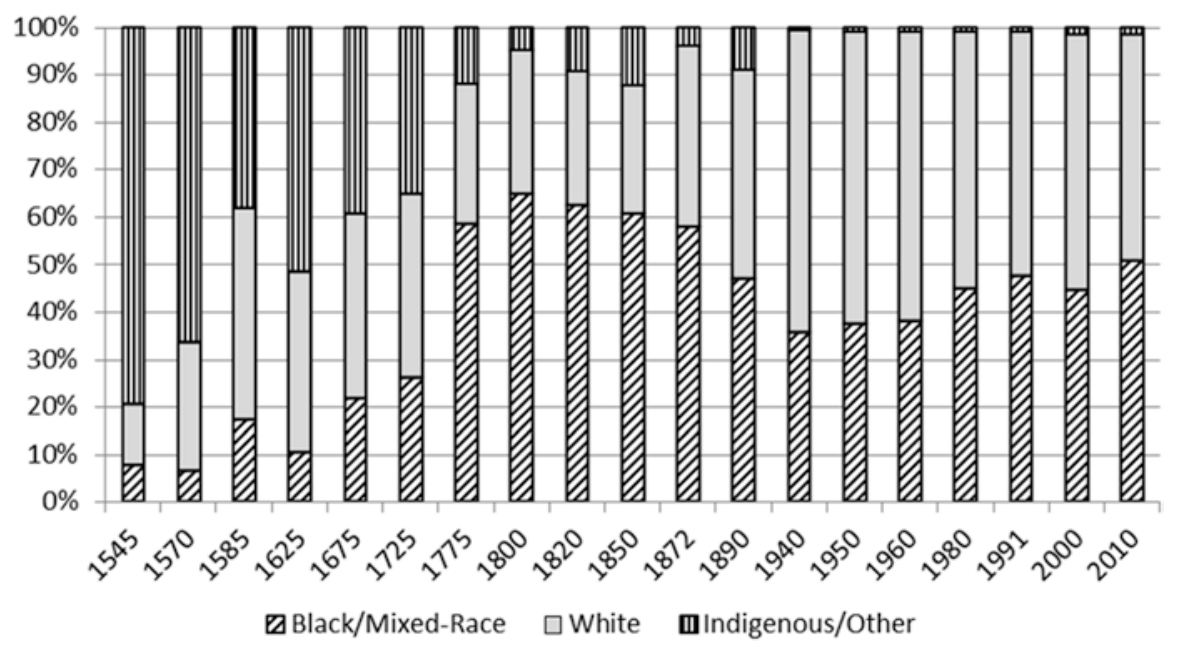

Fig. 1 The racial composition of Brazil. Sources: Figures before 1850 are from Bucciferro (2013; for 1825-1850, these refer to regional censuses across proximate years excluding the state of Ceará); the population and its racial makeup for the periods from 1872 to 2010 are from the IBGE (http://seriesestatisticas.ibge.gov.br/): "Tendências demográficas: uma análise dos resultados da amostra do censo demográfico 2000," Rio de Janeiro: IBGE (2004); 2010 Demographic Census; Directoria Geral de Estatística (1930[187?]), "Recenseamento do Brazil 1872/1920"; Censo demográfico 1940/2010; "Estatísticas do Século XX," Rio de Janeiro: IBGE (2007) in Anuário Estatístico do Brasil, Rio de Janeiro: IBGE 54 (1994)

(Harris et al. 1993; Silva and Leão 2012): the first of these studies involves an experiment which indicates a substantially different racial distribution depending on whether the official term (parda) or vernacular term (morena) is used to refer to the mixed-race population; the latter cites wide variation in the size of the black population depending on how it is defined, as well as a differing perception of race and discrimination among pardos. These results are consistent with Bailey et al. (2013), who show that alternative combinations of racial subcategories could result in Brazil having either a white or a black majority.

The potential drawbacks of the current configuration have not been overlooked, however. In the 1976 household survey, individuals were asked both an open-ended question on race and one with the four standard options (branca, parda, preta, or amarela): just six racial categories - including branca, parda, and preta, as well as morena, morena-clara, and clara-encompassed $94 \%$ of respondents (Wood et al 1988). Although morena was as common a response in the open question as was parda in the structured one (34\% of respondents in each instance), its usage is perhaps too general to function as a census category (Telles 1995). ${ }^{3}$

\footnotetext{
${ }^{3}$ A similar survey was conducted by the newspaper Folia de São Paulo in 1995 that produced consistent results; also, interviewers recorded what they perceived as the person's race and found that people of higher socioeconomic status were more likely to classify into "whiter" categories than those assigned by interviewers (Silva 2001).
} 
Racial identity may be fungible, but the schemas employed in Brazil nonetheless correspond to real social divisions, shaped by ancestry as well as class: the progressive "whitening" of the population was a result of racial mixing and the higher fertility/lower mortality of whites, not only the implicit incentive for pretos and pardos to self-select as pardos and brancos (Ribeiro 1995). Although the current categories of race are oversimplified, they reflect the heritage of Brazilian people and are preferable to a simple white/nonwhite dichotomy which groups together indigenous, African, and Asian elements.

\section{Race and the Labor Force}

This section recounts social, political, and economic developments as they affected whites and Afro-Brazilians after independence, across six time periods which mark key changes in their relative status: the Imperial Era (1822-1889), First Republic (1889-1930), Vargas Era (1930-1945), Second Republic (1946-1964), Military Rule (1964-1985), and Return to Democracy (1985 to present). The independence of Brazil contrasts other Latin American countries because a constitutional monarchy was formed, as opposed to a republican democracy, and slavery expanded, contrary to being abolished.

\subsection{The Imperial Era}

The royal court relocated to Rio de Janeiro upon Napoleon's 1807 invasion of Portugal; João VI became king in 1816, returned to Portugal in 1821, and the ensuing year his son Pedro I declared Brazil independent and himself emperor (Merrick and Graham 1979). Pedro I abdicated in 1831 and was succeeded by Pedro II, only 5 years old, who was crowned in 1840 and served until the republican coup of 1889 . While there was much continuity with the colonial era, this period spanned the unprecedented expansion of the southeast slave economy, suspension of the international slave trade in 1850, and ultimate abolition of slavery in 1888.

Coffee-whose cultivation was introduced into São Paulo during the mid1700s and spread to Rio de Janeiro, Espírito Santo, and Minas Gerais (Filho 1952) - surpassed sugar as Brazil's most valuable export by the 1830s (Bethell and Carvalho 1989). To satisfy growing labor demand, the external and internal slave trades reached new heights: An estimated one million African slaves disembarked in Brazil between 1801 and 1825 and another million between 1826 and 1850 , together $42 \%$ of the entire volume of the slave trade (Trans-Atlantic Slave Trade Database). Internally, up to 200,000 slaves were transported by sea from northern to southern states between 1850 and 1888 (Klein 1971); substantial numbers also migrated to the southeast from the interior states of Mato Grosso, Goiás, and Minas Gerais. 
For coffee producers, investment in slaves yielded above average rates of return around 12-15\% (Mello 1977). To quantify the relative standard of living of slaves, I consider the fraction of earnings which they would have received in goods and services (e.g., clothing, food, and medical care) versus the wages of free workers. The ratio of free to slave "wages" is based on monthly slave hire rates from Journal de Comerçio advertisements compiled by Mello; slave productivity in coffee from Soares (1860), Taunay (1939), and Conrad (1972); and estimated annual earnings of immigrants on coffee plantations from Dean (1976) and Hall (1969).

In Fig. 2, the daily hire rate paid to the slave owner is shown against the value of goods and services consumed by a slave, half the daily earnings of an immigrant family (colono), and the going wage rate for a day laborer (camarada) from 1870 to 1915. The "in-kind wage rate" corresponds to the difference between the gross and net hire rates, or the cost of slave maintenance. The immigrant family wages, with two working adults, and slave hire rates are not very different, but the family could potentially double its income by selling subsistence crops or animals and was provided with housing: the immigrant family money wage is therefore a good proxy for the earnings of an adult.

The individual daily colono money wage (calculated as one-half of the family wage) is relatively close to the average value of goods and services received by slaves per day. Including proceeds from the sale of subsistence crops estimated by Dean (1976), the colono daily wage approximates the daily slave hire rate. Both, however, are below the going rate paid to day laborers. This does not imply that

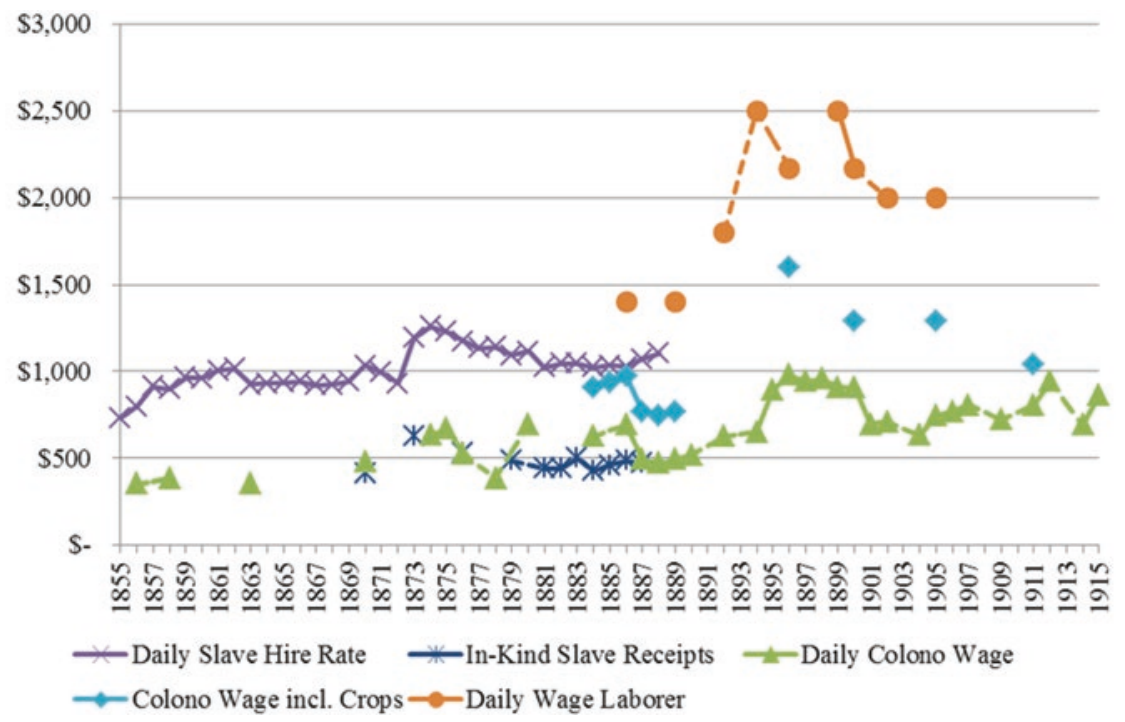

Fig. 2 Daily wages for slave/free workers, 1855-1915 (Nominal Milreis). Sources: Slave hire rates and in-kind slave receipts (cost of slave maintenance) are from de Mello (1977); colono wages, including and excluding crops, and day-laborer (camarada) wages are from Dean (1976) and Hall (1969); daily earnings based on 52 6-day workweeks 
camaradas were better off: on the contrary, their employment was relatively infrequent and annual wages were probably at or below those of colono families. In 1886, slaves received in kind just $35 \%$ of the daily wage of a free laborer.

Slaves were not just producing coffee but employed in every conceivable occupation, from gang laborers on the plantations to shipbuilders and urban merchants (Klein and Luna 2010). In relative terms, however, they formed less than half of the black-and-mulatto population. ${ }^{4}$ The free Afro-Brazilian population was a growing majority: circa $1825,61.0 \%$ of the population was black or mulatto but "only" one-third (33.2\%) was enslaved; circa 1850, $62.8 \%$ of the population was of African descent with one-quarter (25.5\%) enslaved; and in 1872, 58.0\% was black or mulatto and less than one-sixth $(15.2 \%)$ slaves. ${ }^{5}$

The numbers of free Afro-Brazilians, as well as their diverse employments and those of slaves, give the impression that discrimination was relatively subdued (e.g., Luna and Klein 2004). Flory (1977) considers the ambiguous nature of race after independence: free and slave blacks were often treated indifferently by contemporary legislation - vagrancy laws did not explicitly mention race, for instance (but were selectively enforced) - and the citizenship of free native-born blacks was recognized by the 1824 constitution. Periodicals catering to mulattos were founded in the 1830 s, but race was more frequently referred to within the context of politics rather than discrimination.

The topic of race was nominally taken up in the press and public discourse, but deeper issues were at stake which could not be articulated. As Pierson (1942) has implied, social mobility existed for people of mixed descent - the "mulatto escape hatch" referred to by Degler (1971) - yet it was limited and beyond the reach of the third of the population who were slaves. Brazil was already an outlier in the international context: the Haitian revolution (1794) and cessation of the north-Atlantic slave trade (1807) were decades passed.

In spite of gestures that it would end the international trade, it was condoned until 1850 when the British intervened and escorted intercepted slaves back to Africa (Bethell 1970). The newly inelastic supply of labor prompted panic. The basis for continued economic growth was connecting labor with abundant land on the frontier and this was at risk; although there were many native Brazilians, they were overwhelmingly in the subsistence sector and withdrawn from the money economy (Furtado 2006[1959]). Cognizant of the potential end to slavery, planters began to experiment with European immigrant labor.

The movement towards abolition accelerated after 1850: in 1871, the Law of the Free Womb declared the children of slave mothers were free upon maturity and gave

\footnotetext{
${ }^{4}$ For example, the population of Mariana, Minas Gerais, included 22,130 free blacks/mulattos compared to 19,020 enslaved blacks/mulattos and 8914 whites (Bergad 1996). In 1775, among the combined populations of Pará, Rio de Janeiro, and Rio Grande do Sul, $45 \%$ were slaves and $55 \%$ free (regional censuses compiled by Alden 1963). On the positive growth of Afro-Brazilian populations in Minas Gerais, see Boxer (1962) and Russell-Wood (1982).

${ }^{5}$ Sources: circa 1825 and 1850, data are from state censuses in Klein and Luna (2010); 1872 and 1890, national censuses (IBGE). The slave population is from Stein (1957) and Conrad (1972), as published in Hasenbalg (1978).
} 
slaves the right to purchase their own freedom; the Sexagenarian Law followed in 1885, which freed slaves over 60 years of age; and the Golden Law ended slavery altogether in 1888 (Andrews 1991). Even though the princess regent signed the law, it was not a political victory: active rebellion by slaves had made abolition imminent and the monarchy was overthrown the following year.

\subsection{The First Republic}

Freedom brought its challenges to former slaves in Brazil. In the southeast, discrimination by employers and ex-slaves' demands for independence led to the latter's substitution by European immigrants. In other regions, after the immediate upheaval of abolition, life resumed a pattern similar to the previous regime. There was noticeable variation, however, in the adaptation of workers to the new situation. Abolition was a mixed blessing in that it awarded slaves freedom but not necessarily a material improvement in quality of life.

Racism, prevalent at the end of the nineteenth century, contributed to employers' preference for workers from Europe but cannot fully explain it. If there were large numbers of freed slaves (libertos) and other Brazilians (trabalhadores nacionais) available, why were planters determined to hire European immigrants? On one side, whites blamed Afro-Brazilians for the disruptions in the labor force associated with abolition (Ianni 1962); on the other, freed slaves only desired to return to the plantation on certain terms, and not the money wage per se.

The conditions under which ex-slaves would transform into wage laborers were very limited (Furtado 2006[1959]): if freed slaves were given a "subsistence" salary the old system would remain fundamentally unchanged, but if there were abundant unoccupied lands they would prefer to engage in subsistence agriculture. In Brazil, the northeast sugar zone was already fully settled and bound by the caatinga (scrublands) to the west, under which circumstances the labor of former slaves could be secured at a relatively low wage; in the southeast coffee zone, in contrast, lands were abundant and wages relatively high.

Free blacks wanted to distance themselves from the plantation because physical work was culturally considered demeaning and associated with slaves (Ianni 1962). Afro-Brazilian families withdrew women and children from the fields, and occasionally the workforce entirely; immigrant families, in contrast, supplied female and child labor in order to make ends meet, an attractive feature for employers (Andrews 1991). The solution to the labor scarcity problem was consequently to flood the market with immigrants and thereby drive down wages.

Beginning in 1881, programs were created in collaboration with the São Paulo provincial government to subsidize the transportation of migrants from Europe to Brazil. The Society for the Promotion of Immigration was created in 1886 and worked with the province until its dissolution in 1895 (when the government assumed this function), having facilitated the immigration of nearly 220,000 people (Hall 1969). The immigration program was successful: Compared to 195,000 
immigrants who arrived in Brazil between 1870 and 1889, immigration between 1890 and 1909 totaled 1,100,000, half of whom $(515,000)$ were Italian (Kodama 2007). In the 1890s, about as many immigrants entered São Paulo as there were slaves in all of Brazil the year before abolition. ${ }^{6}$

Many labor arrangements existed on the fazendas (plantations), but immigrants to São Paulo commonly became colonos; other salaried positions were camaradas and empreiteiros. The colonos, named for the groups of homes they inhabited among the groves, received a fixed monetary income for maintaining a certain number of coffee trees plus a variable payment depending on the volume of the harvest (Furtado 2006[1959]). ${ }^{7}$ The camaradas, who commonly resided on the plantation in dormitories (usually remodeled slave quarters), were individual laborers paid daily or monthly (Stein 1957; Monsma 2006). Finally, empreiteiros (or, more precisely, gangs of laborers working under an empreiteiro, or contractor) travelled from plantation to plantation completing jobs at a flat rate (Stein 1957).

The estimated daily wages of a typical colono family between 1884 and 1915 are presented in Fig. 2. ${ }^{8}$ Wages were favorable for immigrant families in the years around abolition, declined in real terms from 1892 to 1894, and then spiked in 1895 when the value of output per worker reached an all-time high above $\$ 2,000,000$ réis. After 1900, the increasing price level and stagnant earnings prompted hundreds of thousands to return migrate: on net, only 50,000 immigrants came to São Paulo between 1900 and 1910 (Hall 1969).

In the rest of Brazil, there was no subsidized immigration program and the postabolition experience of Afro-Brazilians varied. Hasenbalg (1978) writes, "In the Northeast, abolition occurred without great readjustment, and the ex-slaves were incorporated into the various fractions of the northeastern peasantry" (p. 153). Domingues (2008a) summarizes three recent works describing the situation of blacks outside São Paulo: (1) In Sergipe, the elite adopted a series of vagrancy laws whose purpose was to force the free population back onto the sugar plantations (Subrinho 2000); (2) in Bahia, freed slaves wanted to limit their labor in the sugar industry as much as possible, and dedicate more time to subsistence farming (Filho 2006); and

\footnotetext{
${ }^{6}$ The overall slave population of Brazil in 1887 was 723,419 (Conrad 1972); between 1890 and 1899, 734,985 immigrants entered São Paulo (Kodama 2007; from Instituto de Estudos Brasileiros, 1973).

${ }^{7}$ Hall (1969) describes the wages on São Paulo coffee plantations: in 1884, the fixed payment (carpa) was about $\$ 50$ réis per 1000 trees plus $\$ 500$ réis per $50 \mathrm{~L}$ of coffee; in 1895 , it was $\$ 90$ and $\$ 600$ réis; in 1904, $\$ 60$ and $\$ 450$ réis; and in 1914, $\$ 80$ and $\$ 400$ réis, respectively. After adjusting for the price level (using the cost of rice as a proxy), he concludes that real wages declined by more than $50 \%$ between 1884 and 1914 .

${ }^{8}$ Each worker tended an average of about 3000 trees and produced $1500 \mathrm{~kg}$ of coffee per year, the equivalent of 25 sacks or 100 arrobas, based on Filho (1952) - yields are based on 3000 trees per worker; Sobrinho (in Hall 1969) - figures refer to the 1890s in São Paulo; Carvalho de Mello (1977) - based on slave yields during 1850-1888 period; Dean (1976) - based on 225 arrobas produced by two-adult family; Hall (1969) - estimate based on aggregate figures for 1910-1914; Klein and Luna (2010) - no. of trees based on 543 plantations during early 1880s, yield/worker from 1820s plantations; Oliveira (in Klein and Luna 2010) - yield/slave referring to 1854; and Stein (1957) - planter's approximation of average output per slave.
} 
(3) in Juiz de Fora, Minas Gerais, some libertos stayed with their former employers while others migrated to the city in search of work (Guimarães 2006).

In Vassouras (northeast São Paulo State), blacks refused to work under conditions associated with slavery. According to Stein (1957), former slaves faced less competition with immigrants because they went to the more profitable plantations of the west; black and mulatto women resigned from field and domestic labor after abolition, but many eventually returned at a piecemeal rate, likewise with men, who were pressured back onto the plantations (by vagrancy laws, for example) and took up positions as camaradas or colonos not altogether different from their previous occupations. In the city of São Paulo, blacks in many occupations (e.g., artisans, small merchants) were substituted by foreigners; new arrivals found only inconstant and menial work (Fernandes 1965; Hasenbalg 1978). Immigrants comprised the majority of the industrial workforce; while this may owe to their relative mobility, they regularly hailed from rural areas and had little previous urban manufacturing experience (Leff 1982).

Knowledge of racial inequality during the early twentieth century is limited because there was only one national census (1920) and it omitted race. A new data source on occupational segregation in São Paulo, however, reveals widespread employment inequality: incident reports (Boletins de Ocorrências) collected from 1912 to 1920 , including information on race and occupation, suggest the wholesale exclusion of blacks from certain jobs. These statistics (from Jacino 2012) are combined with salary data from the 1920 São Paulo census (Table 1), making it possible to calculate the extent of wage inequality caused by occupational segregation.

Blacks tended to be employed in lower paying occupations: they were overrepresented as domestic servants and underrepresented in construction, clothing, health, and liberal professions. Nonetheless, there was proportional representation of blacks among operators (unskilled factory workers), carpenters, painters, and shoemakers. If there was hypothetically no discrimination by race within each occupation, then the average black worker would have earned $\$ 4046$ réis per day compared to $\$ 4911$ réis for the average white worker - in other words, the average income of Afro-Brazilians could have been no greater than $82 \%$ of whites.

It was actually far less than that because of wage discrimination within job classes. According to Domingues (2003), a woman advertised her domestic service in the black journal $O$ Alfinete in 1921 at a rate of $\$ 60,000$ to $\$ 80,000$ réis per month (then thought "exorbitant"). This amount corresponds to \$2000 to \$2667 réis per day, versus $\$ 2640$ earned by the average female domestic and far short of the average $\$ 3750$ (\$112,500/year) for a native-born worker. Adjusting for the racial distribution of the Brazilian population, blacks or mulattos may have been paid wages that were around $50 \%$ of white workers within the same industry. ${ }^{9}$

\footnotetext{
${ }^{9}$ In São Paulo State, the census reported that $82 \%$ of the population was Brazilian and $18 \%$ was foreign in 1920; furthermore, the best estimate from Fernandes (1965) of the black or mulatto share in the overall population of São Paulo City is $9 \%$. About $11 \%$ of the native-born population was therefore Afro-Brazilian, and the average wage of white Brazilian domestics would have been several percentage points higher than that for national workers.
} 
Table 1 Racial segregation and wages by occupation, São Paulo, 1920

\begin{tabular}{|c|c|c|c|c|}
\hline Industry and occupation & Whites & Blacks & Total & Avg. wage \\
\hline \multicolumn{5}{|l|}{ Domestic service } \\
\hline Domésticos & 12,185 & 3191 & 15,376 & $\$ 2759$ \\
\hline \multicolumn{5}{|l|}{ Agriculture } \\
\hline Lavradores & 241 & 0 & 241 & $\$ 5391$ \\
\hline Lenheiros & 108 & 0 & 108 & $\$ 4979$ \\
\hline Tropeiros & 102 & 0 & 102 & $\$ 4062$ \\
\hline Agrónomos & 31 & 0 & 31 & $\$ 4049$ \\
\hline Lenhadores & 28 & 0 & 28 & $\$ 4392$ \\
\hline Leiteiros & 179 & 36 & 215 & $\$ 4115$ \\
\hline \multicolumn{5}{|l|}{ Civil construction } \\
\hline Pedreiro & 731 & 84 & 815 & $\$ 7268$ \\
\hline Oleiros & 137 & 0 & 137 & $\$ 6000$ \\
\hline Marmoris tas & 96 & 0 & 96 & $\$ 6727$ \\
\hline Pintores & 289 & 53 & 342 & $\$ 3205$ \\
\hline Eletricistas & 216 & 0 & 216 & $\$ 6197$ \\
\hline \multicolumn{5}{|l|}{ Transportation } \\
\hline Carroceiro & 1871 & 60 & 1931 & $\$ 4374$ \\
\hline Maquinistas da Railway & 42 & 0 & 42 & $\$ 7684$ \\
\hline \multicolumn{5}{|l|}{ Metalwork } \\
\hline Mecânicos & 721 & 0 & 721 & $\$ 8821$ \\
\hline Ferreiros & 144 & 0 & 144 & $\$ 8228$ \\
\hline Caldeireiros & 121 & 0 & 121 & $\$ 9547$ \\
\hline Polidores & 53 & 0 & 53 & $\$ 5626$ \\
\hline Fundidores & 42 & 0 & 42 & $\$ 8405$ \\
\hline Torneiros & 42 & 0 & 42 & $\$ 7506$ \\
\hline Serralheiros & 6 & 5 & 11 & $\$ 7380$ \\
\hline \multicolumn{5}{|l|}{ Wood } \\
\hline Carpinteiros & 415 & 61 & 476 & $\$ 6433$ \\
\hline Marceneiros & 84 & 0 & 84 & $\$ 7409$ \\
\hline \multicolumn{5}{|l|}{ Textiles } \\
\hline Tintureiros & 162 & 30 & 192 & $\$ 5363$ \\
\hline Tecelões & 137 & 0 & 137 & $\$ 6307$ \\
\hline \multicolumn{5}{|l|}{ Clothing } \\
\hline Alfaiates & 432 & 102 & 534 & $\$ 6382$ \\
\hline Bordadeiras & 108 & 0 & 108 & $\$ 3700$ \\
\hline Costureiras & 150 & 0 & 150 & $\$ 3911$ \\
\hline Chapeleiros & 72 & 0 & 72 & $\$ 6500$ \\
\hline Sapateiros & 307 & 41 & 348 & $\$ 5687$ \\
\hline \multicolumn{5}{|l|}{ Operators (general) } \\
\hline Operários & 9137 & 1351 & 10,488 & $\$ 5700$ \\
\hline Foguistas da Inglesa & 54 & 0 & 54 & $\$ 5819$ \\
\hline
\end{tabular}


Table 1 (continued)

\begin{tabular}{|c|c|c|c|c|}
\hline Industry and occupation & Whites & Blacks & Total & Avg. wage \\
\hline \multicolumn{5}{|l|}{ Commerce/proprietors } \\
\hline Empregados no comércio & 2089 & 150 & 2239 & $\$ 8974$ \\
\hline Capitalistas & 60 & 0 & 60 & $\$ 48,077$ \\
\hline \multicolumn{5}{|l|}{ Health } \\
\hline Barbeiros & 66 & 0 & 66 & $\$ 2564$ \\
\hline Enfermeiros & 84 & 0 & 84 & $\$ 5929$ \\
\hline Médicos & 65 & 0 & 65 & $\$ 10,121$ \\
\hline \multicolumn{5}{|l|}{ Liberal professions } \\
\hline Professores & 97 & 0 & 97 & $\$ 12,019$ \\
\hline Advogados & 61 & 0 & 61 & $\$ 9615$ \\
\hline Engenheiros & 30 & 0 & 30 & $\$ 12,543$ \\
\hline Total obs./avg. wage & 30,995 & 5164 & 36,159 & $\$ 4787$ \\
\hline
\end{tabular}

Sources: Occupational distribution by race and sex (not shown) is from Boletins de Ocorrências spanning 1912-1920 in Sao Paulo, compiled by Ramatis Jacino (2012). Mean daily nominal wages for Sao Paulo state are principally from the 1920 Recenseamento do Brasil, Vol. V, part 2 ("Salarios"), complemented by some national wage figures from this source, and in a few instances annual wage data for neighboring Rio de Janeiro in 1920 (based on 52 6-day workweeks) from Eulalia Lahmeyer Lobo, História do Rio de Janeiro (1978)

In some aspects, abolition brought more equality among races - now citizens, former slaves could choose where to live and work - and in others, it brought less libertos were often relegated to inferior employments than previously held. In much of the country, repression and a lack of options for blacks impeded broader material improvements in their welfare; in the southeast, massive immigration operated to undercut wages and push blacks into the subsistence sector or insecure urban employment. Nationalist sentiment after the Revolution of 1930, however, opened up new opportunities for Afro-Brazilians.

\subsection{The Vargas Era, Second Republic, Military Rule, and Return to Democracy}

During the First Republic, institutions of black civil participation were fomenting. Numerous societies (beginning with Clube 28 de Setembro in 1897) and periodicals (starting with A Pátria in 1899) were established to discuss issues pertinent to Afro-Brazilians (Domingues 2007). This culminated in the early 1930s, when black organizations mobilized support and garnered political influence. The black movement would produce tangible benefits for workers, but would fail to breach higher level political constraints.

Getúlio Vargas overthrew the republican government in 1930 with the support of landowners in his home state of Rio Grande do Sul, as well as Minas Gerais and the 
northeast (Andrews 1991). Afro-Brazilians, who had suffered under the Republic, initially supported Vargas; in turn, he helped integrate them into politics and the economy. The Ministry of Labor was established and the Law of Nationalization of Labor passed in 1931, which required that at least two-thirds of the industrial workforce be native Brazilian (Andrews 1991).

The Brazilian Black Front (FNB) was established in 1931 and by 1936 it had thousands of members and 60 delegates in other states (Domingues 2008b). The organization supported Vargas because, like him, it championed Brazilian nationalism. The FNB promoted the well-being of blacks, and even established an elementary school and health clinic, but became increasingly affiliated with fascism. Disillusionment with the Estado Novo (New State) lessened the imperative for political organization, but the following period was nonetheless one of notable economic progress for blacks (Andrews 1991).

After Vargas lost hold of power, new groups would lead the Afro-Brazilian movement: namely the União dos Homens de Cor, founded in Porto Alegre in 1943, and the Teatro Experimental do Negro, founded in Rio de Janeiro in 1944 (Domingues 2007). The UHC sought to "raise the economic and intellectual level of people-ofcolor" (p. 108), and the TEN promoted Afro-Brazilian culture and anti-discriminatory legislation. The situation of blacks and mulattos nonetheless remained very different from that of whites: the literacy rate for whites was $46.9 \%$ in 1940 and $52.7 \%$ in 1950, versus $22.6 \%$ in 1940 and $25.7 \%$ in 1950 for nonwhites (Hasenbalg 1978). In São Paulo, however, the rate of growth of industrial employment among Afro-Brazilians was comparatively high (Hasenbalg and Salazar 1994).

The military coup of 1964 marked the beginning of the dissolution of progressive Afro-Brazilian societies (Domingues 2007). As stated by Lovell (1999): "Military leaders quickly denounced any criticism of racial democracy as an 'act of subversion' and brutally silenced all opposition movements through imprisonment, censorship, and decree" (p. 400). The race/color question was removed from the 1970 census; partial information is available from other sources for 1976, but statistics on racial inequality are generally unavailable until 1980. In the 1976 National Household Survey (PNAD), whites earned on average 2.8 times more than blacks (3433 $\mathrm{Cr} \$$ to $1210 \mathrm{Cr} \$$ ), and 2.0 times more than people of mixed race (3433 Cr\$ to $1722 \mathrm{Cr} \$$ ); Silva (1985) estimates that $32.9 \%$ of the difference between white and mixed-race individuals is attributable to discrimination, and $26.3 \%$ of that between blacks and whites.

Only in 1978 did black civil society reemerged in the public sphere, with the foundation of the Movimento Negro Unificado (MNU) or Unified Black Movement (Domingues 2007). From the 1980s forward, efforts to eliminate racial discrimination grew and with them public awareness of and scholarship on race. The new generation of Afro-Brazilian organizers, inspired by pan-Africanism and the US black power movement, emerged with a more militant orientation after two decades of suppression by the dictatorship (Andrews 1992).

Many improvements in the social status of Afro-Brazilians followed: the MNU adopted the term "negro" for both blacks and mulattos, and it lost the negative connotation it had during the First Republic; the holiday commemorating abolition was moved from the 13th of May to November 20th, and the 13th was named the 
National Day for the Denunciation of Slavery; school curricula were revised, recognizing multiculturalism and the historical role of blacks; and African cultural heritage was generally asserted (Domingues 2007). In the political arena, the Partido do Movimento Democrático Brasileiro (PDMB) held majority control of the government after 1982 and created a state agency, the Conselho de Participação e Desenvolvimento da Comunidade Negra, directed towards protecting the rights of the black community (Andrews 1992). Over the 1990s and 2000s, improvements in income, life expectancy, and education were greater for blacks than for whites (Charão 2014).

The last decade has witnessed some promising, yet controversial, developments in the effort against discrimination: In 2003, the Secretary of Policy for the Promotion of Racial Equality was established by law (http://www.seppir.gov.br). Its broad charge is to aid in the creation and implementation of public policies regarding racial equality, including the National Program of Affirmative Action enacted on the 13th of May 2002 under direction of the Ministry of Justice, Secretary of State for Human Rights (http://www.planalto.gov.br).

\section{Trends in Racial Inequality from Abolition to the Present}

Important strides have been made in Brazil towards racial equality, but are recent advances part of a larger trend or do they form a unique historical episode? The previous section describes the experience of whites (brancos) and Afro-Brazilians (pretos and pardos) over the past two centuries. This section reports available quantitative evidence on absolute and relative changes, by race, in life expectancy, literacy, education, occupation, and income.

\subsection{Life Expectancy}

Available statistics on life expectancy at birth for whites (brancos) and nonwhites (pardos and pretos), and the difference between them, are presented in Table 2. The white/nonwhite dichotomy is shown here because it was standard in the sources where these figures were published; hereafter, each race is presented separately.

Table 2 Life expectancy at birth (years) by race, 1950-2008

\begin{tabular}{l|c|l|l|l|c}
\hline & 1950 & 1960 & 1980 & 1991 & 2008 \\
\hline White & 47.5 & 54.7 & 66.1 & 70.8 & 73.1 \\
\hline Nonwhite & 40.1 & 44.7 & 59.4 & 64.0 & 67.0 \\
\hline Difference & 7.4 & 10.0 & 6.7 & 6.8 & 6.1 \\
\hline
\end{tabular}

Source: Data from the 1950 and 1980 censuses, as presented in Wood et al. (1988), and Lovell (1999), who adds the 1960 figures; data for 2008 are from LAESER (2010; p. 197/9) based on the 1991/2000 censuses and Ministry of Health 1997-2000 micro-data 
As of 1950 , life expectancy at birth was 47.5 years for whites and 40.1 years for nonwhites - a difference of 7.4 years that increased to 10 years a decade later. The white/nonwhite difference in life expectancy at birth is much lower today than it was in 1960: the largest gain in terms of race equality was between 1960 and 1980, although this gap slightly increased in the 1990s. It appears that recent experience reports a steeper decline than the average since 1980.

\subsection{Literacy}

The comparative illiteracy rates of racial groups in Brazil are illustrated in Fig. 3 (white $=1.00$ ) based on census data (for 1970, when figures are not available, the linear trend is shown). Asian illiteracy rates went down relative to whites through 1960, were flat from 1960 until 1991, and then rose after 1991. Black/mixed-race illiteracy was increasing compared to whites, who were becoming literate at a faster rate, and only falling during the 1990s. Indigenous illiteracy is at a high level, and was also increasing in relative terms from 1960 onwards, with the exception of the decade after 1990.

Prior to 1940 , there is no literacy information by racial group in the censuses. The figures shown for 1900, 1910, 1920, and 1930 are the illiteracy rates for the 70-79, 60-69, 50-59, and 40-49 cohorts in the 1950 census: individuals who would

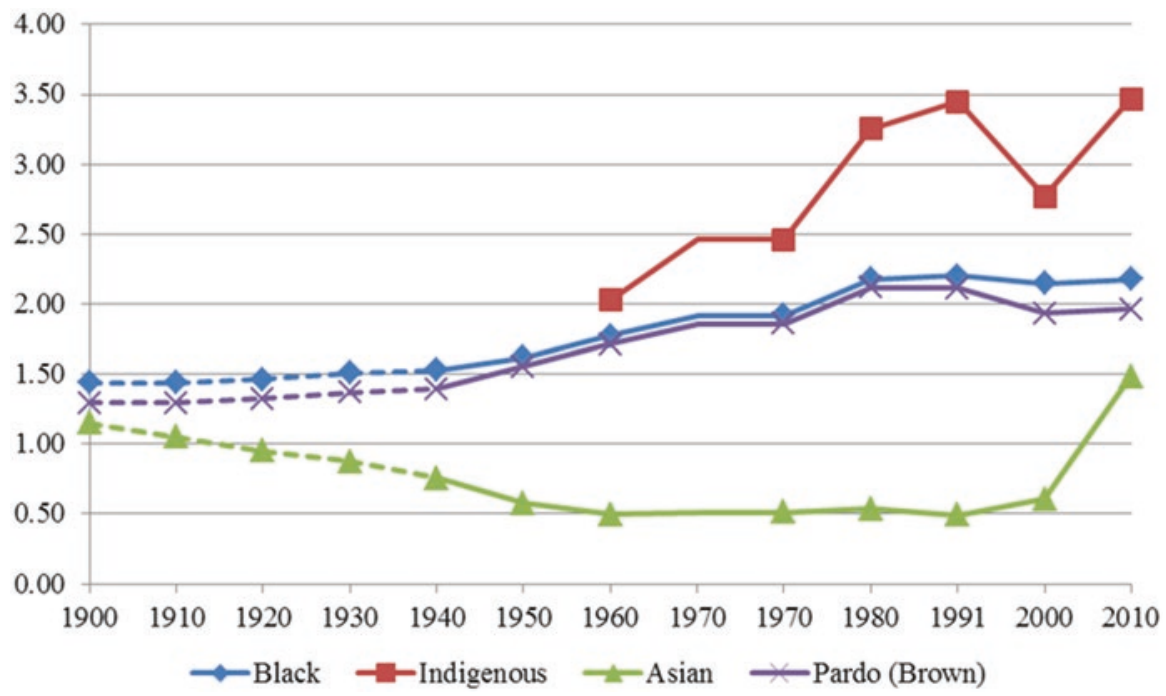

Fig. 3 Illiteracy of racial groups in Brazil relative to whites. Sources: Recenseamento Geral do Brasil 1940, 1950. IBGE census microdata 1960, 1980, 1991, 2000, 2010 from the Minnesota Population Center, Integrated Public Use Microdata Series (IPUMS), International. Minneapolis: University of Minnesota, 2014. Dotted lines correspond to the 40-49 to 70-79 cohort illiteracy rates in 1950 
have been from 20 to 29 in each respective decade, and having literacy levels typical of the population. This method is similar to that of Musacchio et al. (2014), but more robust because the sample is older: the illiteracy rates of the 30-39 racial cohorts in 1950, for instance, are within 5\% of those for the 20-29 cohorts in 1940, whereas the 15-19 and 5-9 age groups differ by as much as $66 \%$.

The illiteracy levels of all groups noticeably declined across the twentieth century: they ranged from $81 \%$ for blacks to $40 \%$ for Asians in 1940, compared with $29 \%$ for indigenous peoples and just $8 \%$ for whites in 2010 . This process accelerated after 1980 - there was an impressive drop in the indigenous illiteracy rate during the 1990s - although in the last decade illiteracy among Asians increased, possibly as a result of migration. Relative declines for whites outpaced those of blacks/mulattos between 1940 and 1980, but stabilized afterwards and Afro-Brazilian illiteracy fell versus whites during the 1990s; there was convergence after 1980, with the exception of a comparative jump in indigenous illiteracy after 2000.

\subsection{Education}

There are various measures of educational completion but the one which is comparable across the twentieth century, and particularly meaningful in terms of individual capabilities and public policy, is primary school completion. Figure 4 presents the

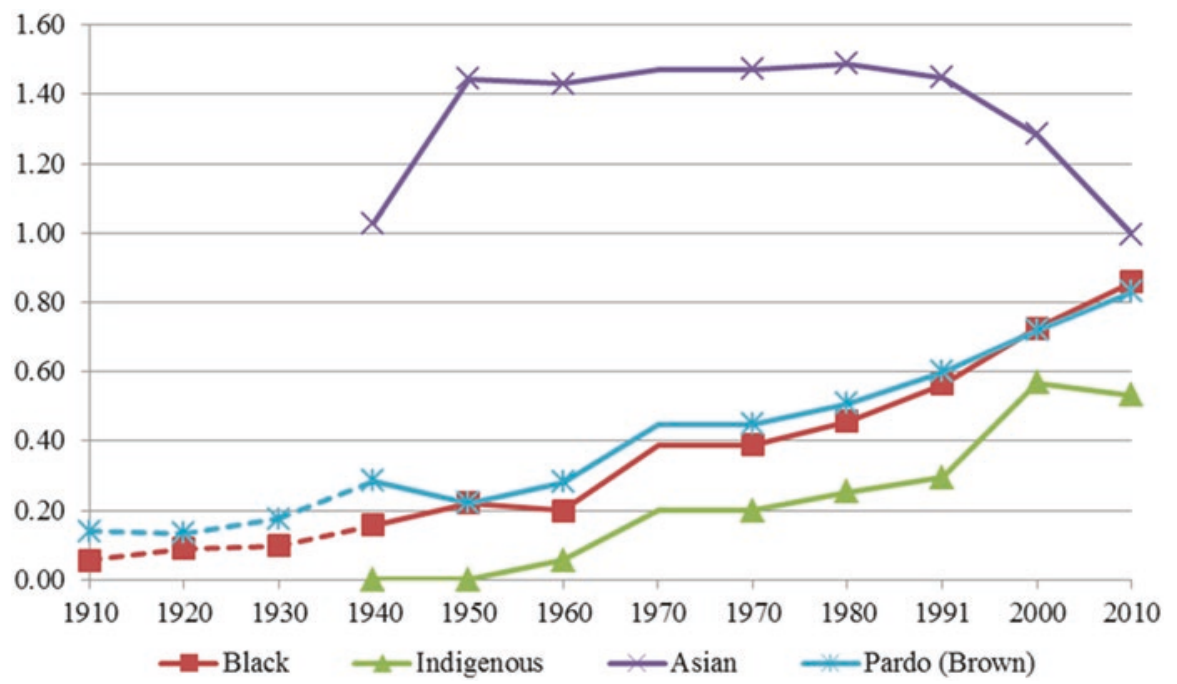

Fig. 4 Relative primary education achievement, 1910-2010. Sources: Recenseamento Geral do Brasil 1940, 1950. IBGE census microdata 1960, 1980, 1991, 2000, 2010 from the Minnesota Population Center, Integrated Public Use Microdata Series (IPUMS), International. Minneapolis: University of Minnesota, 2014. Observations for 1910-1930 correspond to 56-60 age cohorts in 1960 (Musacchio et al. 2014) 
Table 3 Average years of schooling, 1976-2008

\begin{tabular}{l|l|l|l|l}
\hline & 1976 & 1986 & 1998 & 2008 \\
\hline White & 4.5 & 5.4 & 6.8 & 8.3 \\
\hline Nonwhite & 2.7 & 3.9 & 4.7 & 6.5 \\
\hline Difference & 1.8 & 1.5 & 2.1 & 1.8 \\
\hline
\end{tabular}

Sources: Figures from PNAD household surveys; the 1976 and 1986 figures are published in Silva and Hasenbalg (2000), and 1988-1998-2008 overlapping series in LAESER (2010)

percent of individuals within each race who report having completed primary school, defined as grades one through four. The responses are standardized for the 1940/1950 and 1960-2010 periods. ${ }^{10}$ Five percent of the sample had attained a basic education in 1940: $13 \%$ in 1950; $9 \%$ in $1960 ; 26 \%$ in $1980 ; 33 \%$ in $1991 ; 42 \%$ in 2000; and $51 \%$ in 2010.

There were sustained gains in primary educational attainment among mixedrace, black, and indigenous peoples: black or mulatto attainment shows an increasingly positive trend, going from $10 \%$ in 1910 to $84 \%$ of whites in 2010 . Indigenous peoples were less likely to have reported completing primary school, and the size of the relative gap with Afro-Brazilians was roughly constant between 1940 and 1980 (ranging from 18 to 22\%), and wider in 1991 and 2000. Asians were at parity with whites in both 1940 and 2010, with completion rates about $40 \%$ higher in intermediate years. In general, there was a smooth convergence of educational attainment after 1980, with the indigenous experience of the 2000s being the sole outlier.

Table 3 presents data for whites and nonwhites from an alternative source, annual household surveys, for another education indicator, average years of schooling. The PNAD was first administered in 1976, and then every year after 1980, and is used in most current studies of racial inequality. In terms of average years of schooling, there was essentially no trend over the 1976-2008 periods.

In 1976, whites had on average 1.8 years more schooling than nonwhites, and 1.5 extra years a decade later; by 1998, however, the achievement gap was higher than before, and in 2008 at the same level as in 1976. This pattern is somewhat congruous with Fig. 4-education is increasing for all groups in reversing magnitudesbut there was greater educational equality in primary school attainment as opposed to average years of schooling, likely explained by proportionally higher secondary and tertiary completion among whites.

\footnotetext{
${ }^{10}$ The 1940/1950 censuses report those who have completed elementary, middle, or superior education, whereas the standardized responses after 1960 include many intermediate classifications. The frequency with which responses are coded into certain categories alternates, but only significantly in 2010 when there were many vague replies.
} 
Table 4 Occupational segregation by race

\begin{tabular}{l|c|l}
\hline Year (sample) & D-D index & $\%$ Afro-Brz. \\
\hline 1907 (S. Carlos) & 8.98 & 12.80 \\
\hline 1920 (S. Paulo) & 36.51 & 17.24 \\
\hline 1936 (Bahia) & 54.12 & 75.35 \\
\hline 1940 & 11.55 & 36.34 \\
\hline 1950 & 12.79 & 37.79 \\
\hline 1960 & 6.49 & 36.29 \\
\hline 1980 & 21.07 & 43.34 \\
\hline 1991 & 17.58 & 46.32 \\
\hline 2000 & 17.43 & 43.91 \\
\hline 2010 & 14.30 & 48.46
\end{tabular}

Sources: 1940 and 1950 Recenseamento geral do Brasil; 1960-2010 decennial censuses from IBGE National Census Microdata, IPUMS International, University of Minnesota (2014); São Carlos 1907 from Monsma (2006); São Paulo 1920, Boletins de ocorrência in Jacino (2012); and Bahia 1936, Pierson (1942)

\subsection{Occupational Distribution}

The degree of occupational segregation over time is examined using census data from 1940 to 2010, as well as three regional observations for previous decades when the national censuses did not consider race: urban São Paulo circa 1920 from the incident reports compiled by Jacino (2012); São Carlos (western São Paulo state) in 1907 from Monsma (2006); and Salvador (the capital of the northeast state of Bahia) for 1936 from Pierson (1942).

I adopt the Duncan and Duncan Index of occupational segregation, which was originally applied to gender (Wolff 2009). The D-D index is the summation across occupations of the absolute value of the difference between the percent of total white $\left(w_{i}\right)$ and black $\left(b_{i}\right)$ employees in occupation $i$, divided by two $\left(\mathrm{DD}=\Sigma\left|w_{i}-b_{i}\right| / 2\right)$. The results are shown in Table 4, along with the percent of the population that was Afro-Brazilian. ${ }^{11}$

Occupational segregation tripled between 1960 and 1980, from moderate levels in the 1940s and 1950s, and has since gradually declined back to its earlier level. It dropped from 12.8 to 6.5 (on a scale of 100) between 1950 and 1960, and then reverted to a high of 21.1 in 1980 . The degree of employment segregation decreased during the 1980s and 2000s, settling slightly above its 1940/1950 level in 2010. Before 1940, it was relatively high in urban São Paulo (36.5) and Bahia (54.1), and

\footnotetext{
${ }^{11}$ The employment segregation indices are based on a consistent grouping of individual jobs into ten common occupational classes: public administration, agriculture-fishing-forestry, commerce of real property, commerce of merchandise, national defense-public safety, manufacturing industry, extractive industry, liberal professions, services-social activities, and transport-communications.
} 


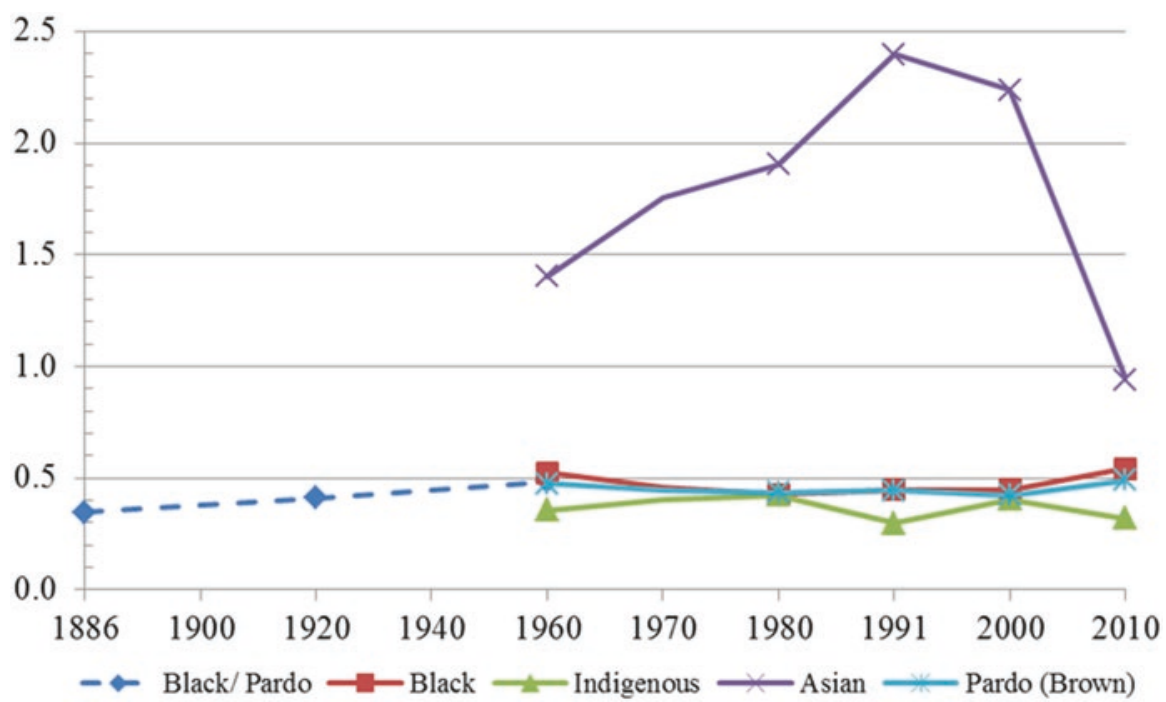

Fig. 5 Brazilian income by racial group relative to whites. Sources: IBGE census microdata 1960, 1980, 1991, 2000, 2010 from the Minnesota Population Center, Integrated Public Use Microdata Series (IPUMS), International. Minneapolis: University of Minnesota, 2014. Dashed series based on author's calculations

relatively low in rural western São Paulo (9.0). There appears to be more segregation where blacks comprised a greater share of the population, although the sample sizes and methods of data collection require caution in making such comparisons.

\subsection{Income}

Life span, literacy, education, and employment-human capital in general-affect one's income; hence, racial inequality must also be salient in terms of earnings given the disparities in these areas. I consider differences in reported income by race using the 1960-2010 census micro-data. The average real annual income was \$111 in 1960: $\$ 236$ in 1980; \$430 in 1991; \$645 in 2000; and \$749 in 2010. ${ }^{12}$ Figure 5 displays the ratio of each race's mean income to that of whites (the highest in 2010).

The paths of relative incomes after 1960 are relatively flat: the income gap widened through 1980 and has since narrowed, with little change during the 1990s - an unexceptional record in comparison with the improvement of the preceding 75 years. The ratios of indigenous- and Asian-to-white incomes fell between 2000 and 2010,

\footnotetext{
${ }^{12}$ Mean incomes expressed in 2010 reales by the author adjusting for currency revaluations and using consumer price indices from 10/1980 to 7/1999 and 1/1994 to 10/2014 (IBGE, Sistema Nacional de Índices de Preços ao Consumidor), as well as benchmark 1960-1980 inflation rates from Allen (2009).
} 
but there was a rise in the relative incomes of whites and Afro-Brazilians - the two predominant racial groups in Brazil. ${ }^{13}$ LAESER (2010) confirms that the multiples of average per capita nonwhite to white household earnings for 1988, 1998, and 2008 were $0.433,0.417$, and 0.505 , respectively.

The pre-1960 trend of Afro-Brazilian-to-white income-based on slave in-kind earnings and urban occupational segregation, respectively — shows a big positive change: In terms of goods and services consumed, a typical black or mulatto slave in 1886 could earn $35 \%$ of a free white worker; in São Paulo, the employment distribution and classified advertisements suggest that blacks or pardos in 1920 may have earned $41 \%$ of whites; the census data for 1960 give a corresponding figure of $49 \%$. Although Afro-Brazilians today earn just over half of whites, this is more than in 1960 which makes it the smallest recorded income gap.

\section{Conclusion}

Racial equality in Brazil has been getting a lot of attention, and for good reason: health, education, employment, and income have become more similar across races, accompanied by increased public policy and activism targeting discrimination. This chapter explores changes in these variables for pretos, pardos, brancos, indigenas, and amarelos after 1900 and between whites (brancos) and Afro-Brazilians (pretos and pardos) since independence in 1822 .

During the Imperial Era (1822-1889), Afro-Brazilians comprised a majority of the population and the fraction enslaved gradually diminished until abolition in 1888. The transition to freedom under the First Republic (1889-1930) was difficult as libertos had to compete with immigrants in the south; elsewhere, freed slaves settled back into agricultural life or moved to cities. The status of blacks improved during the Vargas Era (1930-1945) as industrial positions opened; was set back by the repressive Estado Novo; advanced along with the economy in the Second Republic (1946-1964); and was again hindered under Military Rule (1964-1985).

In summary, economic outcomes improved for most races relative to whites from 1940 to 1960 , though their comparative levels of education and life expectancy worsened. The general trend was poor from 1960 to 1980 in terms of occupational segregation and the size of the income gap, but there were relative advances in life expectancy and completion of basic education. Over 1980-2010, there was a positive overall experience in terms of reducing racial inequality, although gains were somewhat muted during the 1990s. The situation of Afro-Brazilians is better than it was a few decades ago, and race has become imbued with pride; yet progress has been irregular and opportunity remains far from equal.

\footnotetext{
${ }^{13}$ Real incomes were strictly increasing over this 50-year span, with the exception of 2000/2010 when there was a stunning $51 \%$ decline in the average income of Asians and moderate $8 \%$ reduction in that of indígenas. There were relatively few Asians in Brazil in 2000, but by 2010 their share of the population had doubled.
} 
Acknowledgments The author is grateful to participants at the Latin American Inequality in the Long Run conference (Buenos Aires, 12/2014), above all Jeff Williamson, Luis Bértola, Eustaquio Reis, José Peres-Cajías, and Moramay López-Alonso, as well as the Economic History of Race, Gender, and Class conference (Middlebury, 4/2015), particularly Lety Arroyo Abad, Catalina Vizcarra, Peter Lindert, Jenny Bourne, and Bob Margo. Thanks also go to Renato Araujo da Silva and librarians at the Museo Afro Brasil (São Paulo), periodical staff at the Arquivo Público do Estado de São Paulo, and the Instituto Brasileiro de Geografia e Estatística (IBGE) for assistance in locating source materials.

Open Access This chapter is distributed under the terms of the Creative Commons Attribution 4.0 International License (http://creativecommons.org/licenses/by/4.0/), which permits use, duplication, adaptation, distribution and reproduction in any medium or format, as long as you give appropriate credit to the original author(s) and the source, a link is provided to the Creative Commons license and indicate if changes were made.

The images or other third party material in this chapter are included in the work's Creative Commons license, unless indicated otherwise in the credit line; if such material is not included in the work's Creative Commons license and the respective action is not permitted by statutory regulation, users will need to obtain permission from the license holder to duplicate, adapt or reproduce the material.

\section{References}

Alden, D. (1963). The population of Brazil in the late eighteenth century: A preliminary study. Hispanic American Historical Review, 43(2), 173-205.

Allen, L. (2009). The encyclopedia of money (2nd ed.). Santa Barbara: Greenwood Publishing Group.

Andrews, G. R. (1991). Blacks \& whites in São Paulo, Brazil 1888-1988. Madison: University of Wisconsin Press.

Andrews, G. R. (1992). Black political protest in São Paulo, 1888-1988. Journal of Latin American Studies, 24(1), 141-171.

Arcand, J.-L., \& D'Hombres, B. (2004). Racial discrimination in the Brazilian labor market: Wage, employment, and segregation effects. Journal of International Development, 16, 1053-1066.

Arias, O., Yamada, G., \& Tejerina, L. (2004). Education, family background and racial earnings inequality in Brazil. International Journal of Manpower, 25(3/4), 355-374.

Bailey, S. R., Loveman, M., \& Muniz, J. O. (2013). Measures of 'race' and the analysis of racial inequality in Brazil. Social Science Research, 42(1), 106-119.

Bergad, L. W. (1996). After the mining boom: Demographic and economic aspects of slavery in Mariana, MG, 1750-1808. Latin American Research Review, 31(1), 67-98.

Bethell, L. (1970). The abolition of the Brazilian slave trade: Britain, Brazil and the slave trade question, 1807-1869. Cambridge: Cambridge University Press.

Bethell, L., \& de Carvalho, J. M. (1989). 1822-1850. In L. Bethell (Ed.), Brazil: Empire and republic, 1822-1930 (pp. 45-112). Cambridge: Cambridge University Press.

Boxer, C. R. (1962). The golden age of Brazil. Berkeley: Cambridge University Press.

Bucciferro, J. R. (2013). A forced hand: Natives, Africans, and the population of Brazil, 15451850. Revista de Historia Económica/Journal of Iberian and Latin American Economic History, 31(2), 285-317. 
Campante, F. R., Crespo, A. R. V., \& Leite, P. G. P. G. (2004). Desigualdade salarial entre raças no Mercado de trabalho urbano Brasileiro: aspectos regionais. Revista Brasileira de Economia, 58(2), 185-210.

Charão, C. (2014). O longo combate às desigualdades raciais. Retrieved from http://www.ipea. gov.br/.

Conrad, R. E. (1972). The destruction of Brazilian slavery, 1850-1888. Berkeley: University of California Press.

Dean, W. (1976). Rio Claro: A Brazilian plantation system, 1820-1920. Stanford, CA: Stanford University Press.

Degler, C. N. (1971). Neither black nor white: Slavery and race relations in Brazil and the United States. New York: Macmillan.

Domingues, P. (2003). Uma história não contada: Negro, racismo e branqueamento em são paulo no pós-abolição. São Paulo: Senac.

Domingues, P. (2007). Movimento negro Brasileiro: alguns apontamentos históricos. Tempo, 23, $100-122$.

Domingues, P. (2008a). Decifrando os segredos internos: a transição do trabalho escravo para o livre no Brasil. Iberoamericana, 8(31), 197-205.

Domingues, P. (2008b). A nova abolição. São Paulo: Selo Negro.

Fernandes, F. (1965). A integração do negro na sociedade de classes (Vol. 2). São Paulo: Dominus. Filho, O. B. (1952). A Fazenda do café em São Paulo. Rio de Janeiro: Ministério da Agricultura.

Flory, T. (1977). Race and social control in independent Brazil. Journal of Latin American Studies, 9(2), 199-224.

Furtado, C. (2006[1959]). Formação econômica do Brasil. São Paulo: Companhia das Letras.

Filho, W. F. (2006). Encruzilhadas da liberdade: histórias de escravos e libertos na Bahia (18701910). Campinas, SP: Editora da Unicamp.

Guimarães, E. S. (2006). Múltiplos viveres de afrodescendentes na escravidão e no pos-emancipação: família, trabalho, terra e conflito (Juiz de Fora-MG, 1828-1928). Paulo: Anna-blume.

Hall, M. M. (1969). The origins of mass immigration in Brazil, 1871-1914. Doctoral thesis, Columbia University.

Harris, M., Consorte, J. G., Lang, J., \& Byrne, B. (1993). Who are the whites? Imposed census categories and the racial demography of Brazil. Social Forces, 72(2), 451-462.

Hasenbalg, C. A. (1978). Race relations in post-abolition Brazil: The smooth preservation of racial inequalities. Doctoral thesis, UC-Berkeley.

Hasenbalg, C., \& Salazar, G. (1994). Perspectivas sobre raza y clase en Brasil. Estudios Sociológicos, 12(34), 75-99.

Ianni, O. (1962). As metamorfoses do escravo: Apogee e crise da escravatura no Brasil meridional. São Paulo: Difusão Européia do Livro.

Instituto Brasileiro de Geografia e Estatística. (2000). Brasil: 500 anos de povoamento. Rio de Janeiro: IBGE.

Instituto Brasileiro de Geografia e Estatística. (2008). Síntese de indicadores sociais: uma análise das condições de vida da população Brasileira. Estudos \& Pesquisas, 23, 209-230.

International Labor Organization. (2007). Igualdade no trabalho: Enfrentando os desafios. Geneva: United Nations.

Jacino, R. (2012). O negro no mercado de trabalho em São Paulo pós-abolição - 1912/1920. Doctoral thesis, Universidade de São Paulo.

Klein, H. S. (1971). The internal slave trade in nineteenth century Brazil: A study of slave importations into Rio de Janeiro in 1852. Hispanic American Historical Review, 51(4), 567-585.

Klein, H. S. (2010). The Atlantic slave trade. Cambridge: Cambridge University Press.

Klein, H. S., \& Luna, F. V. (2010). Slavery in Brazil. New York: Cambridge University Press.

Kodama, K. (2007). O sol nascente do Brasil: um balanço da imigração Japonesa. In Brasil: 500 anos de povoamento (pp. 199-213). Rio de Janeiro: IBGE.

Laboratório de Análises Econômicas, Históricas, Sociais e Estatisticas das Relações Raciais (LAESER). (2010). Relatório Annual das Desigualdades Raciais no Brasil, 2009-2010. Rio de Janeiro: UFRJ. 
Leff, N. H. (1982). Underdevelopment and development in Brazil (Vol. 1). London: George Allen \& Unwin.

Loury, G. C. (2002). The anatomy of racial inequality. Cambridge: Harvard University Press.

Lovell, P. A. (1999). Development and the persistence of racial inequality in Brazil: 1950-1991. The Journal of the Developing Areas, 33(3), 395-418.

Luna, F. V., \& Klein, H. S. (2004). Slave economy and society in Minas Gerais and São Paulo, Brazil in 1830. Journal of Latin American Studies, 36, 1-28.

Marteleto, L. J. (2012). Educational inequality by race in Brazil, 1982-2007: Structural changes and shifts in racial classification. Demography, 49, 337-358.

Mello, P. C. de. (1977). The economics of labor in Brazilian coffee plantations, 1850-1888. Doctoral thesis, University of Chicago.

Merrick, T. W., \& Graham, D. H. (1979). Population and economic development in Brazil: 1800 to the present. Baltimore: Johns Hopkins University Press.

Monsma, K. (2006). Symbolic conflicts, deadly consequences: Fights between Italians and Blacks in Western São Paulo, 1888-1914. Journal of Social History, 39(4), 1123-1152.

Musacchio, A., Fritscher, A. M., \& Viarengo, M. (2014). Colonial institutions, trade shocks, and the diffusion of elementary education in Brazil, 1889-1930. Journal of Economic History, 74(3), 730-766.

Pierson, D. (1942). Negroes in Brazil: A study of race contact at Bahia. Chicago/London: University of Chicago Press.

Ribeiro, D. (1995). O povo Brasileiro. São Paulo: Companhia das Letras.

Rossetto, I., \& Paixão, M. (2010). Acesso ao sistema de ensino e indicadores de proficiência. In Relatório annual das desigualdades raciais no Brasil: 2009-2010 (pp. 205-248). LAESER. Rio de Janeiro: UFRJ.

Russell-Wood, A. J. R. (1982). The black man in slavery and freedom in colonial Brazil. London: Macmillan.

Silva, N. d. V., \& Hasenbalg, C. (2000). Tendências da desigualdade educacional no Brasil. Dados, 43(3), 423-445.

Silva, N. D. V. (2001). Race, poverty, and social exclusion in Brazil. In E. Gacitúa, C. Sojo, \& S. H. Davis (Eds.) Social exclusion and poverty reduction in Latin America and the Caribbean. Washington, DC: World Bank.

Silva, N. D. V. (1985). Updating the cost of not being white in Brazil. In P. M. Fontaine (Ed.) Race, class, and power in Brazil. Los Angeles: UCLA.

Silva, G. M., \& de Souza Leão, L. T. (2012). O paradox da mistura: identidades, desigualdades e percepção de discriminação entre Brasileiros pardos. RBCS, 27(80), 117-255.

Soares, S. F. (1860). Notas estatísticas sobre a produção agrícola e carestia dos géneros alimentícios no império do Brazil. Rio de Janeiro: Typ. Imp. e Const. de J. Villeneuve e Comp.

Stein, S. (1957). Vassouras: A Brazilian coffee county, 1850-1900. Cambridge: Harvard.

Subrinho, J. M. d. P. (2000). Reordenamento do trabalho: trabalho escravo e trabalho livre no Nordeste açucareiro: Sergipe 1850-1930. Aracaju: Funcaju.

Taunay, A. de E. (1939). Historia do café no Brasil (Vol. 2). Rio de Janeiro: Departamento Nacional do Café.

Telles, E. E. (1995). Racial ambiguity among the Brazilian population. UCLA working paper.

Trans-Atlantic slave trade database. Retrieved 11, 2014, from www.slavevoyages.org.

Wolff, E. N. (2009). Poverty and income distribution (2nd ed.). Malden, MA: Wiley-Blackwell.

Wood, C. H., Alberto, J., \& Magno, de C. (1988). The demography of inequality in Brazil. Cambridge: Cambridge University Press.

Justin Bucciferro is an associate professor of economics at Eastern Washington University. His research centers on the economic history and development of the Americas, addressing the interrelationships between demography, geography, and inequality. He earned a Ph.D. in Economics from the University of Colorado at Boulder and an M.B.A. from Clarkson University. His research appears in the Economic History Review, Economic Anthropology, and the Journal of Iberian and Latin American Economic History. 